\title{
TIWAI
}

\section{Ariana Sutton}

\section{TIWAI}

When the spirits raise their flag,

I gotta get mine too!

This is not a poem.

This is blood, sweat and fears

the tears, you polluted

lie hidden in people's homes.

The bones around Tiwai

the toki in the sand.

Am I at the mercy of your

ruthless hand? Rio Tinto

No! 'cause when the spirits

raise their flags,

I've got mine too

It wavers on the inside

flagging across my heart and instinct.

The wind cleanses me

and tells me what's wrong

And what's right.

Yes. We all know it's wrong

but continue the same song

excusing this denial,'cause

underneath you've all felt

this, for far too long. 
I'll cradle your silence your numbness and your fears. But don't come to silence me, 'cause I took the spirit flag.

The song is on repeat, to deafen the noisy lies we sell ourselves.

We deserve ourselves, in full health, love and connection to a nourished land.

Trust in community leaders, thrusting around in solid form. Upon the rocks, at the point Te Ara a Kiwa.

The mighty southern ocean! you could never be defeated.

Then you remember. Your, your own Leader and the song, the sea and the sovereignty is yours.

Speak for the voiceless. Act for the un-birthed. Feel for the neighbour and love thyself, as pure oceans do.

Ariana Sutton, Kāi Tahu, Kāti Mamoe, Waitaha Ōku Iwi. No Murihiku ia. 